bodily forward on the beach, breaking up into segments in its progress, and carrying fields, trees, and houses along with it. Unquestionably the most appalling disaster of the kind which has happened in recent times was the celebrated Fall of the Rossberg in I806, a mountain lying behind the Rigi, and composed like it of sandstone and conglomerate. In this case also there had been much provious heavy rain, which, filtering along a porous sandy bed inclined at a steep angle towards the valley, undermined the support of the overlying thick sheet of massive conglomerate. The whole hill-side gave way and several villages and hamlets, with somewhere between 800 and 900 people, were buried under the ruins. To this day the scar on the slope of the mountain is unhealed, and the piles of huge angular blocks, even to the further side of the valley, remain as memorials of the homesteads and villagers that lie buried below.

The recent catastrophe at Naini Tal is another illustration of the same geological process. The locality is situated on the soft Tertiary deposits which flank the sub-metamorphic and more ancient crystalline rocks of the Himalaya range that towers behind. It possesses one of the few known sheets of water on the Himalayan slopes, nestling among irregularly shaped hills. There is every reason to believe that these hills have derived their present contour not only from extensive denudation by the heavy rainfall, but also from the operation of former landslips, and that the lake itself, to which the place has owed so much of its attractiveness, lies in a hollow formed by the same cause. It has been suggested that the late accident arose from the cutting of a roadway along the base of the hill. But this seems an altogether improbable and unnecessary supposition. The structure of the ground is itself sufficient to account for landslips, apart altogether from the mere superficial interference of any road-making. According to the telegraphic reports there had been a particularly heavy rain, no less than twenty-five inches having fallen in forty hours. The annual rainfall at Naini Tal is stated to be ninety inches, so that more than a quarter of the whole yearly rain fell in less than two days. But this year, at least, the rainfall must have been greater, for Mr. Commissioner Taylor, who was charged with the care of the roads in the district and met his death in the recent catastrophe, wrote on August 17 last that eighty inches of rain had fallen in the previous two months. By such a violent downpour the loose soil is swept off the surface, deep gashes are cut down the slopes, and every streamlet and river is converted into a torrent of liquid mud. But the furrowed soils and rocks likewise absorb much moisture. The water launched in such a deluge over the ground soaks at once into the more permeable gravelly layers and saturates them. When these are inclined towards lower ground and covered with heavy masses of earth or rock, the conditions for the production of landslips are supplied to the full. And such seems to have been the case in this melancholy Indian disaster.

The question arises, Can any steps be taken to guard against a repetition of the calamity? We may take it for granted that Naini Tal, in spite of its recent visitation, will continue to be a favourite resort from the arid plains below. The chance of an occasional destructive landslip will not deter men from coming year after year to gain renewed health and rest in the pure air of these uplands. It is obviously impossible to prevent landslips, except such minor falls as could not do any extensive damage. The only resource is to fix the sites of stations and houses on such spots as will either be free from risk of accident or on which the risk will be reduced to a minimum. This is mainly a geological question, but it is evidently one of the utmost social importance. Among the able staff of the Geological Survey of India there is no doubt an officer whose services could be made available to examine and report upon the structure of the ground at Naini Tal with special reference to this question. There ought to be first a careful inquiry into the details of the causes that led to the recent sad event, and with the experience thus gained a further inquiry into the safety of the other parts of the settlement and of other hillstations similarly placed. Even in a district liable to destructive landslips sites for houses can probably be so chosen and defended as to be practically exempt from liability to such calamitous visitations as that which we now so heartily deplore. The prodigious amount of rain which in a few days or hours deluges the ground in these regions presents an engineering problem which demands actual Indian experience on the part of those who would successfully grapple with it. Neither geologists nor engineers accustomed only to the comparatively mild rain-storms of Europe can probably realise the magnitude of the difficulty which such disasters as that of Naini Tal presents for their consideration.

\section{ARCTIC NEWS}

$T$ $\mathrm{HE}$ past week has been an unusually interesting one so far as Arctic matters are concerned. First of all we have tidings of the return of the Franklin Search Expedition, sent out from the United States about two years ago, to follow up and unearth if possible some important relics of the Franklin expedition, said to exist among the Eskimo. It may be remembered that upwards of two years ago news reached this country that Mr. Barry, the mate of an American whaler, was told by some Nechelli Eskimo whom he met at Whale Point, Hudson's Bay, that some spoons with Franklin's crest upon them, possessed by the Eslkimo, were received from a party of white men who passed a winter near their settlement, where they all died; and that these men left a number of books with writing in them, which were buried. The tale seemed very doubtful, and those best acquainted with the history of Franklin search expeditions considered that it was scarcely necessary to act on the gossip of the Eskimo. However, the people of the United States, who have all along manifested a generous enthusiasm in behalf of the Franklin expedition, thought otherwise, and by private enterprise an expedition was sent out in the summer of 1878 , under Lieut. Schwatka, to follow up the traces indicated by the Eskimo. This expedition, after an absence of two years, has just returned, and although the success, so far as its immediate object is concerned, has not been great, it has evidently been able to make important additions to a knowledge of the condition of the inhospitable Arctic region traversed, a region rendered classical, if not sacred, by the early and terrible work of Franklin him- 
self. The following telegram in the New York Herald of September 23, from New Bedford, Massachusetts, was the first announcement of the return of the expedition :-

"The Franklin Search Expedition, under the command of Lieut. Schwatka, have returned here. They have discovered and brought southward relics of the two British ships Terror and Erebus, which sailed from London, under Sir John Franklin, in May, 1845. The expedition successfully withstood the greatest amount of cold ever encountered by white men. During sixteen days of a sledge journey, extending over a period of eleven months, the average temperature was $100^{\circ}$ below freezing point. In the summer and autumn of 1879 the expedition made a complete search of King William's Land and the adjoining mainland, travelling by the route pursued by the crews of the Erebus and Terror in retreating towards Back's River. They burnt [? buried] the bones of all remaining above ground, and erected monuments in memory of the dead. Their researches have established the fact that the records of the Franklin Expedition are beyond recovery. They have also learnt that one of Sir John Franklin's ships drifted down the Victoria Straits, and was unwittingly scuttled by the Eskimo, who found it off Grant Point in 1849 . The expedition have brought away the remains of Irving, the third officer of the Terror. From each spot where graves were found a few tokens were selected which may serve to identify those who perished there. They also secured a board which may be of use in identifying the ship which completed the NorthWest Passage."

A few further details have appeared in the subsequent numbers of the Herald, but we must await the arrival of the paper and the publication of Lieut. Schwatka's narrative for full details. Particulars, we are told, are given of the sufferings and hardships endured by Lieut. Schwatka's party, who, however, succeeded in discovering relics of the expedition, and learnt from the natives details of the sufferings it underwent from cold and starvation. The natives related that they saw a small party of officers, believed to be the last survivors of the expedition, black about the mouths and with no flesh on their bones, dragging a boat across the ice. They then disappeared from view, and their skeletons were subsequently found under the boat and in a tent, a prey to wild beasts, and affording evidence that some of them had been eaten by their comrades. Lieut. Schwatka's own party, we are told, made a sledge journey of over 2,819 geographical miles, mostly across unexplored country, and this constitutes the longest sledge journey on record, both as to time and distance; the men it seems lived like the natives.

The sad story of the terrible suffering endured by 105 men who quitted the Erebus and Terror on April 22, I848, ten months after the death of Franklin, is too well known from the narrative of the search party in the Fox under $\mathrm{M}^{\circ} \mathrm{Clintock}$. Ample evidence was found scattered along the shores of King William's Land and Boothia, by which they endeavoured to reach the Fish River Settlements, of the fate of most of the party, many of whom, the Eskimo told $\mathrm{M}^{\prime} \mathrm{C}$ lintock, fell down as they walked, and had to remain unburied. Lieut. Schwatka's party have done what they could to show respect to what remains of the brave and unfortunate band. Unfortunately no written records of the expedition have been found; there was little room to expect that there would. As to the statement about the vessel which completed the North-West Passage, we suppose this must mean that one of the ships had drifted south-westwards so far as to meet with the furthest eastward point reached by Franklin in his earlier expeditions. The records of temperature will be eagerly looked for by meteorologists ; the degree of cold seems to have far exceeded any Arctic temperature on record.

An unfortunate set-off to Lieut. Schwatka's successful return is the news that Capt. Howgate has been again compelled to put back in the Gulnare to St. John's, Newfoundland, the vessel being so unsuited for her work that the proposed expedition to Lady Franklin Bay has had to be abandoned for this year. Capt. Howgate is certainly very unfortunate in his Arctic scheme, though we trust he will not be daunted, but will next year be able to accomplish the foundation of his Polar colony.

Further sad news comes from San Francisco of the Gordon-Bennett expedition in the Jeannette, which set out full of hope not long ago. No tidings can be obtained by the whalers of the expedition, and the relief steamer Corwin had to return owing to the severity of the weather. There is however no more reason for giving up hope than there was in the case of the Payer-Weyprecht expedition, which disappeared suddenly off the Novaya Zemlya coast in 1872 , and returned about two years later with the tidings of the discovery of a new Arctic land. This land, Franz Josef Land, a telegram from Hammerfest informs us, was visited in August by that most daring of yachtsmen, Mr. Leigh Smith. He explored to the west as far as $45^{\circ} \mathrm{E}$. and $80^{\circ} 20^{\prime} \mathrm{N}$, and sighted land from that point about forty miles north-west. No doubt Mr. Leigh Smith's experience this year and Capt. Markham's in the same direction last year, seem to point out that exploration northwards on the basis of Franz Josef Land is hopeful. So long as such exploration is carried on by private enterprise there can be no objection to it, but if Government has any funds to spare for Arctic work during the next few years, they would be expended to the best advantage in enabling this country to join the European and American concert for the establishment of Polar observing stations, from which England is conspicuously absent.

\section{RODD'S BIRDS OF CORNWALL}

The Birds of Cornwall and the Scilly Islands. By the late Edward Hearle Rodd. Edited, with an Introduction, Appendix, and brief Memoir of the Author, by James Edmund Harting. With Portrait and Map. (London : Trübner and Co., r88o.)

7 HE addition of another volume to the already long series of works upon the local avifaunas of Great Britain is not perhaps an event of any very great importance as regards ornithology in general. Yet the name of the late Mr. Edward Hearle Rodd of Penzance is so wel known to British naturalists, and the county in which his observations were made is a land of such special interest, that there can be no doubt of the present volume being acceptable to a wide circle of readers.

At the time of his death it was generally understood that Mr. Rodd had in preparation a general work upon the birds of his native county. This work, however, as we are now informed by Mr. Harting, had only so far advanced as to "consist of a transcript of various notes on the ornithology of Cornwall, communicated by the author to the pages of the Zoologist arranged in chrono- 